\title{
Microbial-induced carbonate precipitation applicability with the Methane Hydrate-bearing layer microbe
}

Toshiro Hata Dr. ENG ${ }^{1}$, Alexandra Clarà Saracho², Stuart K. Haigh Ph.D ${ }^{3}$, Jun Yoneda, Dr. ENG ${ }^{4}$, Koji Yamamoto, Ph.D 5

${ }^{1}$ Professor, Department of Civil and Environmental Engineering, Hiroshima University, HigashiHiroshima-Japan. https://orcid.org/0000-0002-9092-2636

2PhD Student, Department of Engineering, University of Cambridge, Cambridge, United Kingdom

Postdoctoral Researcher, Laboratory for Soil Mechanics, Swiss Federal Institute of Technology, Lausanne, Switzerland.

${ }^{3}$ Reader, Department of Engineering, University of Cambridge

https://orcid.org/0000-0003-3782-0099

${ }^{4}$ Senior Researcher, National Institute of Advanced Industrial Science and Technology (AIST) https://orcid.org/0000-0002-4569-9922

${ }^{5}$ Director General, Japan Oil, Gas and Metals National Corporation (JOGMEC)

https://orcid.org/0000-0002-3365-1198

Corresponding author:

Toshiro Hata

1-4-1 Kagamiyama, Higashi-Hiroshima, 739-8527, Japan

Phone: +81-82-424-7784, FAX:

Email: thata@hiroshima-u.ac.jp 


\section{Abstract}

Production of methane gas from the methane-hydrate-bearing layer below the deep-ocean floor is expected to be crucial in the future of energy resources worldwide. During the methane gasproduction phase from the methane hydrate with the depressurisation method, the depressurising zone around the production well will lose strength, causing a potential geohazard. In this study, a biomediated treatment to reinforce the methane hydrate layers is proposed. A urease-producing bacterium, Sporosarcina newyorkensis, was isolated for the first time from a pressure core sampled from the Nankai Trough seabed methane-hydrate-bearing layer in Japan. This newly isolated species can survive deep-seabed environments and also enhance the population under nutrient-rich conditions. In addition, it is uniquely characterised with higher urease activities under low-temperature conditions in comparison to the well-known bacterium S. pasteurii. The results of triaxial tests suggest that this bacterium can catalyse the precipitation of calcium carbonate through urea hydrolysis, which enhances the soil strength below of the ocean floor and hence reinforces the production well. This will not only make methane gas extraction safer but may also reduce sand production in the well, making extraction operations more efficient and cost effective.

\section{Keywords}

Ground improvement; Soil stabilisation; Laboratory tests, Pressure core; Gas hydrate 


\section{List of notations}

AIST: National Institute of Advanced Industrial Science and Technology, Japan

CD triaxial compression test: Consolidated Drained triaxial compression test

MICP: Microbially Induced Calcite Precipitation

P-core: Pressurise core

PCR-DGGE: Polymerase Chain Reaction-Denaturing gradient gel electrophoresis

PCS: Pressure Coring System

PNATS: Pressure-Core Non-destructive Analysis Tools

PT: Pressure/Temperature

TSB: Trypticase Soy Broth 


\section{Introduction}

The deep-ocean floor environment is the last frontier for the development of the next-generation of energy resources such as methane hydrate. Although this frontier remains untouched by humans, it has been home to deep-sea microbial communities for millennia. Researchers and engineers need to develop new energy production methods that minimise geohazards such as submarine landslides and sand production resulting from oil and gas production operations. For gas production from unconsolidated methane-hydrate-bearing sediments, measures to limit sand and water production while not disturbing the gas production are required. If the strength and permeability of soil can be controlled through microbial induced carbonate precipitation (MICP) treatment, the technique can contribute towards stable gas production. Conventional mitigation practice relies on the injection of artificial substances such as cement and water glass, which are potentially damaging to the delicate deep-sea ecosystems. In recent years, bio-mediated geotechnics has focussed on the development of the next-generation of ground improvement techniques targeting an increased soil strength (Whiffin, Van Paassen and Harkes, 2007; Al Qabany and Soga, 2013; Montoya and DeJong, 2015; Terzis and Laloui, 2019), reduced internal erosion (Jiang et al., 2016; Jiang and Soga, 2017; Clarà Saracho and Haigh, 2018a, b, Clarà Saracho et al 2020a,b) and lakebed stability (Hata et al., 2019), amongst others. Most of these bio-mediated ground improvements focus on the use of ureaseproducing bacteria as catalysts for calcium carbonate precipitation through urea hydrolysis, (Van Paassen, 2009; Dejong et al., 2013).

The existing body of research within the field of biogeotechnics has primarily focused on Sporosarcina pasteurii. This is a high-urease activity microbe isolated from the surface soil and is found to increase the soil strength (Bang, Galinat and Ramakrishnan V, 2001). Another strength-increasing ureaseproducing bacterium, Sporosarcina aquimarina, was isolated from the estuaries of South Korea. This thrives in seawater, having a high salt tolerance (Yoon et al., 2001: Hata et al., 2013). However, the severe conditions of the deep-ocean environment, with low temperatures and high pressure, may hamper the growth of these microbes. Along this line, Clarà Saracho et al. (2020a) found an increased sensitivity of urease activity to pressure at temperatures near those of the original isolation environment, which is of major importance for the application of MICP in the deep sea. Therefore, the utilisation of microbes of deep-sea origin would be preferable. Similar urease-producing microbes 
from deep-ocean environments have not been previously reported in the context of sand production mitigation.

The difficulties of undertaking research on MICP for these deep-sea sediments is compounded by the difficulty in obtaining undisturbed soil samples from stable methane hydrate deposits. Conventional coring techniques are unable to maintain the high-pressure conditions while extracting the samples from the ocean floor to the surface, triggering the decomposition of the methane hydrate and destroying the core.

An alternative technique is pressure coring (PCS), which maintains the high-pressure conditions below of the seabed floor throughout transport to the surface environment. Several types of pressure coring systems have been developed in the past 30 years (Pettigrew, 1992; Dickens et al., 1997; Takahashi et al., 2001; Fujii et al., 2009). In 2012, Hybrid-PCS (Kubo et al., 2012), was applied to the hydrate-bearing layer of the Daini-Atsumi Knoll in the eastern Nankai Trough (Inada and Yamamoto, 2015). The results obtained indicated a core recovery rate of around 73\% (Yamamoto, 2015; Suzuki et al., 2015; Priest et al., 2015). Pressure cores were cut and stored in the storage chamber and transferred to the onshore laboratory with pressure and temperature control. These pressure-core samples were sub-sampled while under pressure, and their hydraulic and mechanical properties such as permeability, strength and particle size distribution were investigated (Santamarina et al., 2015; Yoneda et al., 2015; 2017). In the same project, the first bio-subsampler and reactor for pressure cores were deployed and used to count cells that were incubated with different culture conditions (Santamarina et al., 2015). Pressure coring and analysis technology are essential techniques for the successful characterization of grain and pore fluid properties of deep-sea reservoirs. These are crucial to the development of practical technologies to extract energy from methane hydrate.

In this study, Sporosarcina newyorkensis, a urease-producing bacterium newly isolated from the pressure cores extracted from the Daini-Atsumi Knoll, was used to evaluate the feasibility of MICP (Microbial Carbonate Induced Precipitation) for ground improvement in the deep-sea using native bacteria. Bacterial viability and strength properties, i.e. cohesion (c) and internal friction angle $(\varphi)$, were investigated with respect to the other well-known ureolytic strains described above: S. pasteurii and S. aquimarina. The MICP process was investigated with the following tests: 1) measurement of 
the microbes' urease activity at different temperatures, 2) comparison of the calcium carbonate precipitation rate and 3) consolidated drained (CD) triaxial compression tests.

\section{Isolation of urease-producing microbes from a P-core}

\subsection{Outline of P-core sampling and preparation steps}

The pressure core was extracted from the AT1-MC well at the Daini-Atsumi Knoll, an outer ridge of the forearc basin along the northeast of the Nankai Trough (Fig. 1). (Suzuki et al., 2015) using a hybrid-PCS tool. The sampling depth (mBSF) was approximately $316 \mathrm{~m}$, corresponding to the bottom of the methane-hydrate-bearing zone at which the estimated in-situ pressure and temperature conditions were $13 \mathrm{MPa}$ and $13^{\circ} \mathrm{C}-14^{\circ} \mathrm{C}$, respectively.

After sample recovery during which the PT conditions remained within the stability boundary, pressure-core processing took place at $20 \mathrm{MPa}$ and $4^{\circ} \mathrm{C}$. The P-wave velocity, bulk density, and X-ray computed tomography image displayed a good quality of core sample.

The extracted P-core was subsequently cut into less than $5-\mathrm{cm}$ sub-samples from the original pressure core using a PNATS (Pressure-Core Non-destructive Analysis Tools) system (Yoneda et al., 2015; Jin et al., 2016), at AIST (National Institute of Advanced Industrial Science and Technology, Japan) while maintaining the stability of the methane hydrate.

After cutting, the soil sample was depressurised, resulting in the dissociation of the methane hydrate without harming the soil sample structure. The depressurised sample was then stored at a low temperature in a methane gas atmosphere to prevent any change in the microbial diversity, population and enzyme activity prior to MICP evaluation. The soil coring and urease-producing bacterium isolation process is shown in Fig. 2 . 


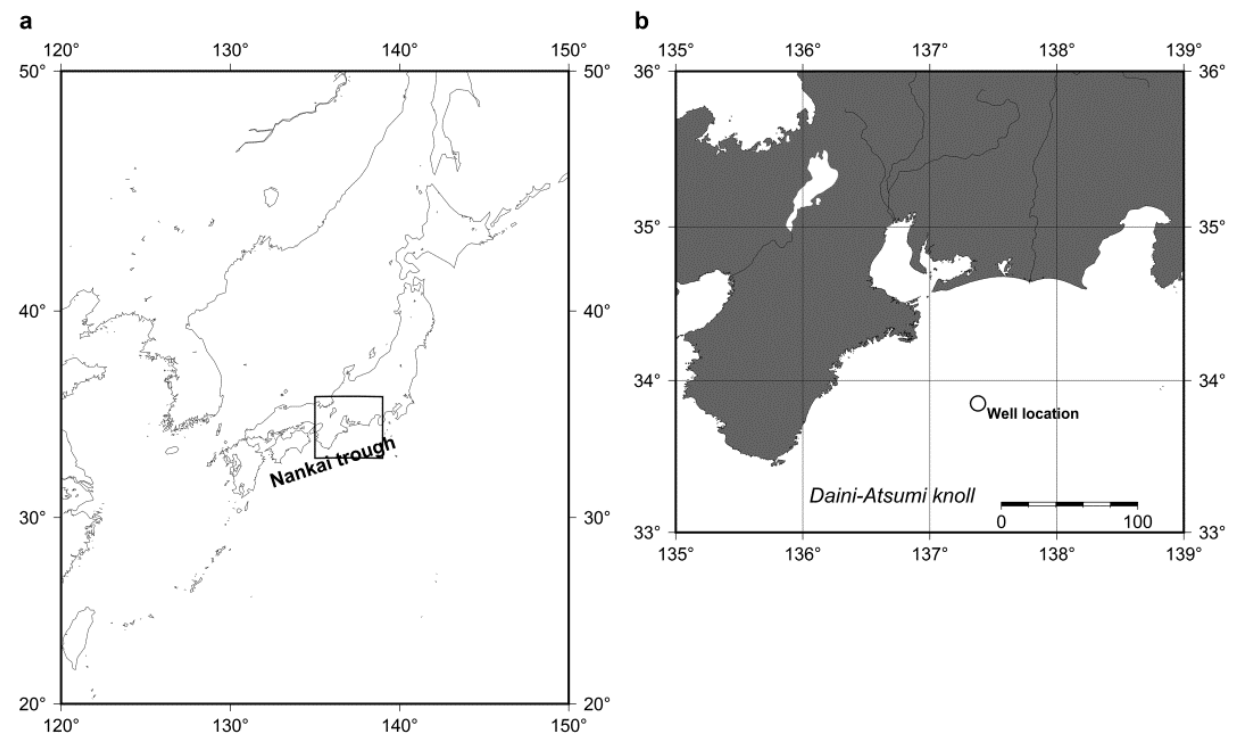

Figure 1. Sample location of this study.

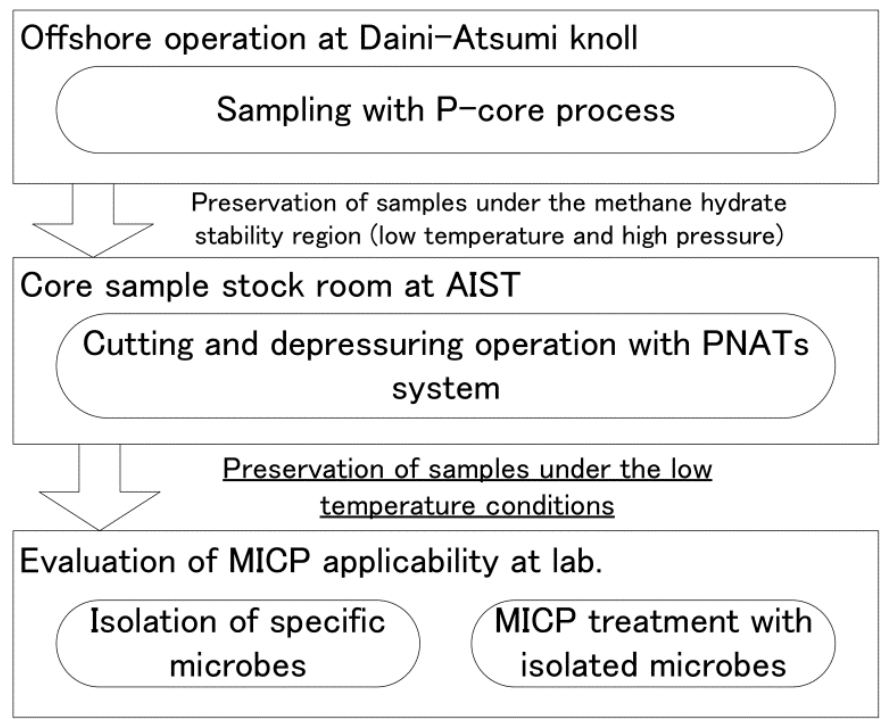

Figure 2. Sample preparation flow prior to laboratory tests.

\subsection{Influence of P-core operations on microbial diversity}

The main objective of the P-core operation was to maintain the original conditions of the methanehydrate-bearing layer during the coring process. Thus, the influence of the P-core operation on the microbial diversity of the sample, including that of the pressurisation process with distilled water, needs to be evaluated using molecular biology methods.

The process and sub-sample locations for this step are shown in Fig. 3. First, the soil DNA from the non-cultivated samples was extracted to evaluate the initial conditions of the depressurised soil 
sample. Simultaneously, pre-bacterial cultivation was started at a constant temperature of $20^{\circ} \mathrm{C}$, with nutrient-rich conditions (Urea $0.15 \mathrm{~mol} / \mathrm{l}$, Yeast extract $6.6 \mathrm{~g} / \mathrm{l}$ ) to increase the population of the ureaseproducing target microbes in the soil samples. The ratio of soil to culture medium was $1: 10$ (i.e. $0.3 \mathrm{~g}$ of soil and $30 \mathrm{ml}$ of culture medium). The $\mathrm{pH}$ and ammonium ion levels sampled from the liquid medium were measured weekly using a pH electrode and ion chromatography respectively. Bacterial DNA extracted from the initial and cultivated samples using PCR-DGGE (Muyzer et al., 1993) were compared to identify the microbial diversity of each sample and to evaluate the effect of the P-core operation. The bacterial urease activity was also measured in the cultivated samples to assess the MICP treatment potential (Whiffin, 2004).

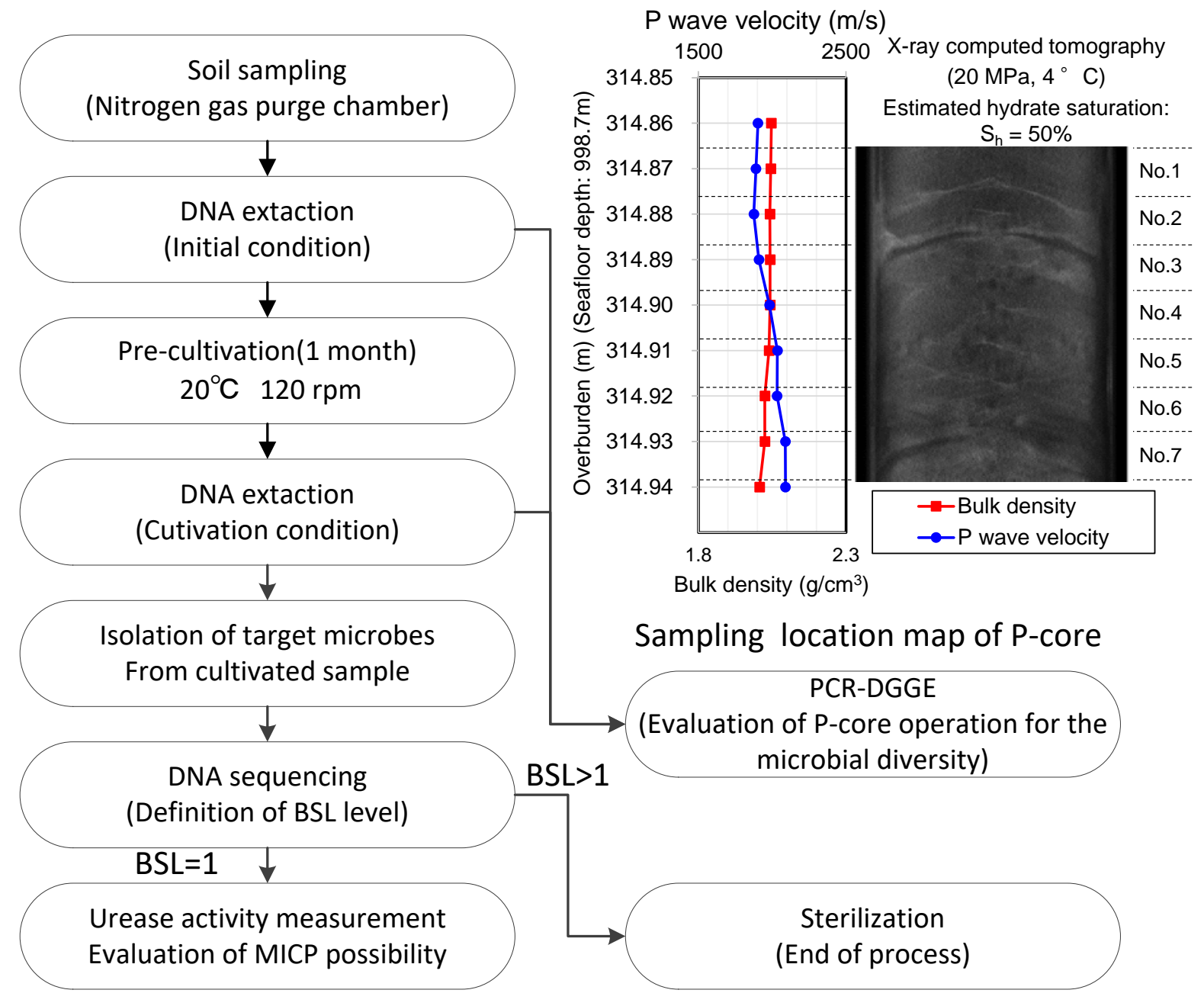

Figure 3. Process flow and sample location of this step.

\subsection{The isolation process of urease-producing bacteria}


Urease-producing bacteria were isolated from the depressurised core sample to evaluate their activity. The cultivated soil samples were collected in sterilised bottles using a nitrogen-gas purge chamber to maintain the samples' original conditions. Following pre-bacterial cultivation, the urease producing bacteria were cultivated using the plate culture method in a medium containing $0.15-\mathrm{mol} / \mathrm{I}$ urea, $6.6-\mathrm{g} / \mathrm{l}$ yeast extract and $15-\mathrm{g} / \mathrm{l}$ agar. After the 3-day cultivation at $30^{\circ} \mathrm{C}$ many types of colonies were observed, and the population of the target microbes was assessed.

A single colony was subsequently isolated and placed on a new bacterial plate. After $20 \mathrm{~h}$, the growth colony was observed using a microscope and checked for contamination. The urease activity of the isolated pure culture was then measured. The highly-urease-producing microbes were studied through DNA sequencing, focusing on the 16SrDNA, to identify the microbial species and the biosafety level (BSL). The DNA sequencing was conducted following Sanger's sequencing method (Sanger et al., 1977).

\subsection{The possibility of MICP treatment with newly isolated microbes}

The feasibility of applying the newly isolated urease-positive bacterium from below the deep-ocean floor, S. newyorkensis, for MICP was investigated through liquid phase and solidification tests. Tests were also performed with urease-producing bacterial strains, S. pasteurii and S. aquimarina for comparison.

\subsubsection{Liquid phase tests}

The liquid phase tests aimed to evaluate the urease activity of the three Sporosarcina strains under different conditions and their calcium carbonate precipitation through microscopic observations. Bacterial samples were cultivated in a medium of trypticase soy broth (TSB) for both S. aquimarina and S. newyorkensis, with NH4-YE medium (ATCC Medium 1376) being used for S. pasteurii. In order to evaluate the effects of low temperature in the deep ocean, samples were cultivated at both $4^{\circ} \mathrm{C}$ and $20^{\circ} \mathrm{C}$ for 4 days in a $50 \mathrm{ml}$ tube at atmospheric pressure. Following cultivation, the urease activity of the microbes was measured using the EC method (Whiffin, 2004). The crystallisation speed and particle shapes achieved during crystallisation were also investigated for the three bacterial species using a polycarbonate plankton counter composed of 0.5-mm mesh with 1.0-mm depth and 0.1-ml liquid volume (MPC-200, Matsunami Glass, Japan) and a biological microscope (CX31, 
Olympus, Japan) set to $100 \times$ magnification with tests being carried out at $20^{\circ} \mathrm{C}$. A cementation solution comprising $0.3 \mathrm{~mol} / \mathrm{l}$ of urea and $0.3 \mathrm{~mol} / / \mathrm{CaCl}_{2}$ was used to initialise $\mathrm{CaCO}_{3}$ precipitation. Additional crystallisation tests were also performed using S. pasteurii and S. newyorkensis at $4^{\circ} \mathrm{C}$. These used an Olympus BX50 microscope, other conditions being the same as those of the original tests.

\subsubsection{Solid-phase tests}

The solid-phase tests evaluated the influence of MICP treatment with the newly isolated microbe $S$. newyorkensis on the soil strength measured using a consolidated drained (CD) triaxial test. A $50 \mathrm{~mm}$ diameter, $90 \mathrm{~mm}$ high triaxial sample of Toyoura sand was prepared at 50\% relative density before being injected with one injection of a bacterial solution that had been cultured using TSB medium for 3 days at $30^{\circ} \mathrm{C}$, which maintained the same O.D.600 (bacterial population) and urease activities. During the cementation process the sample was maintained at a temperature of $20^{\circ} \mathrm{C}$ while either one or three injections of a cementation solution ( $100 \mathrm{ml}$ pure water, $3 \mathrm{~g}$ nutrient broth, $1 \mathrm{~g} \mathrm{NH}_{4} \mathrm{Cl}, 0.212 \mathrm{~g}$ $\mathrm{NaHCO}_{3}, 1.8 \mathrm{~g}$ Urea and $3.33 \mathrm{~g} \mathrm{CaCl}_{2}$ ) were made at 72 hour intervals. Following MICP treatment, specimens were washed with distilled water to exchange the pore water and maintain the samples' stable conditions before carrying out the consolidation drained CD triaxial test. The CD tests were conducted using JGS (Japan Geotechnical Society) standard methods (JGS 0524). After the CD tests, all specimens had their $\mathrm{CaCO}_{3}$ content measured using the acid digestion method with hydrochloric acid (Hata et al., 2019).

\section{Results and Discussion}

\subsection{The influence of microbial diversity on the P-core operation}

In P-core operations, distilled water must be used to maintain the original pressurised conditions such that the methane hydrate remains stable during the cutting and sampling phase. Four centimetres of the P-core sample were used to evaluate the microbial diversity in the sample with PCR-DGGE methods to visualise the microbial community of each sample before and after the cultivation phase. The $\mathrm{pH}$ and ammonium ion concentrations and the results of the PCR-DGGE are shown in Figs. 4 and 5 , respectively. 
a
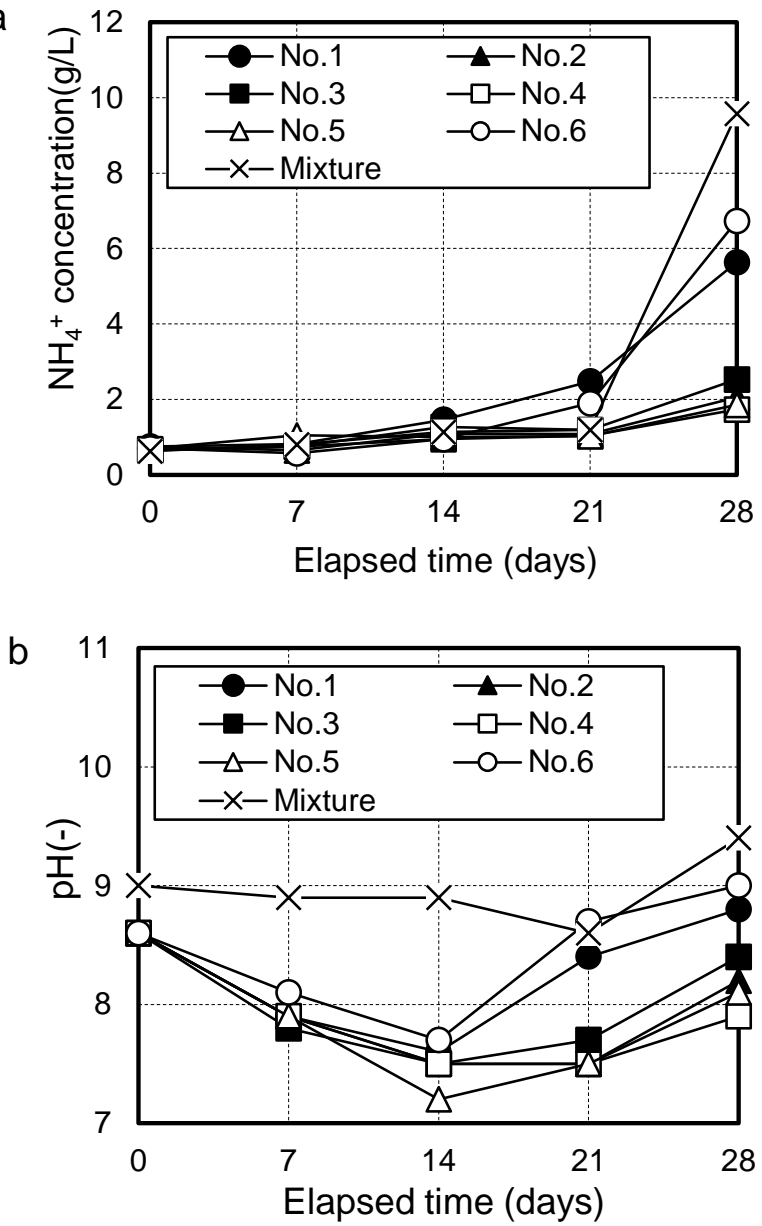

Figure 4. Ammonium ion concentration and $\mathrm{pH}$ trends. 


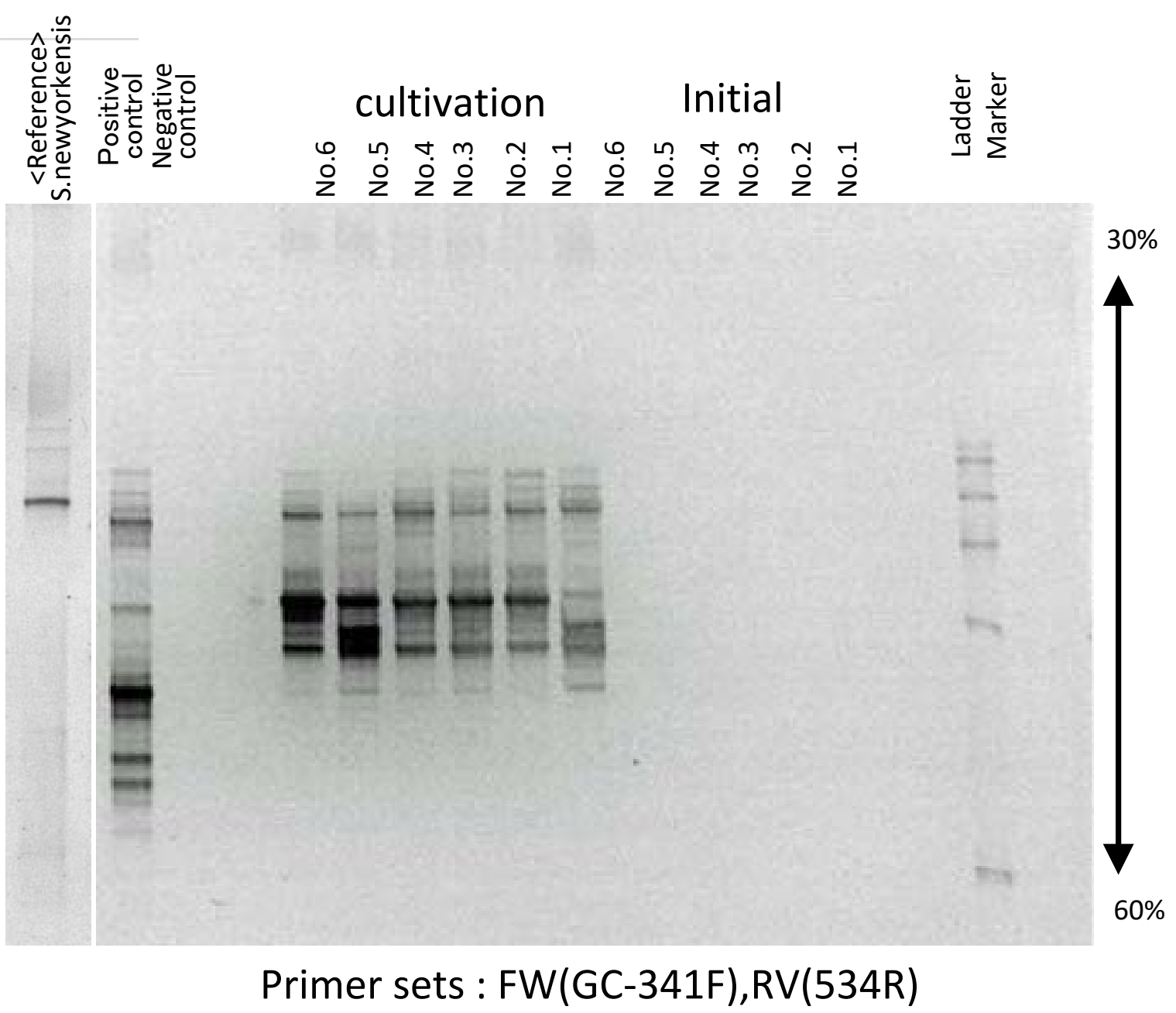

Figure 5. Results of the PCR-DGGE

The ammonium ion concentrations of every sample gradually increased during the test period. These results indicate that urea hydrolysis occurred and that population of urease-producing bacteria increased or activate the urease genes into the samples. The mixed sample that focusses on the homogenising effect, which supposes the operational setup process of the energy production well, showed the highest increase in ammonium ion concentration. The outer side of the P-core samples (No. 1 and 6) (Figure 3) indicated higher ammonium concentrations than the centre and inner side. The $\mathrm{pH}$ of samples 1-6 decreased until day 14 and then increased to day 28 . Only the mixed sample stayed at a stable $\mathrm{pH}$ during the test term. These results indicate that the mixed sample has enhanced levels of urea hydrolysis.

The chemical analysis was verified and confirmed by the PCR-DGGE results shown in Figure 5 . The PCR-DGGE image results show the diversity of microbes in the analytical samples. In this image, the position of each horizontal line indicates a particular bacterial species with the barcoding pattern 
hence indicating information on the microbial diversity. The reference sample shown can be used to identify the line related to S. newyorkensis. For the initial sample (without cultivation) no barcoding pattern can be seen, indicating that the concentration of microbes in the original samples is extremely small and PCR products cannot be detected. The environment beneath deep-seabed exhibits quite poor nutrient conditions and the bacterial population is sparse. The results of PCR-DGGE suggest that the initial P-core samples contain only a small number of microbes. These results suggest that the P-core operation (pressurising with distilled water) does not have much of an impact on the deepocean floor microbial communities, and these initial conditions can be maintained.

Figure 5 also shows the microbial diversity after the samples were cultivated. This shows that cultivation can increase the microbial population and maintain the necessary conditions for ureaseproducing bacteria in the culture medium.

All samples showed different banding patterns. These results indicate that the initial microbial community was maintained within the P-core and during the pre-bacterial cultivation steps without contamination.

\subsection{The isolation of urease-producing bacteria from the P-core}

Urease-producing bacteria were isolated from the mixed sample that showed high ammonium ion generation maintaining its alkaline conditions during the pre-bacterial cultivation step. Thirty ureaseproducing microbes were isolated from the mixture sample. During the measurement of the urease activity, the top three bacteria were selected for DNA sequencing, identification of the microbial species and evaluation of the BSL.

The DNA sequencing revealed that all isolated microbes were of the Sporosarcina species, the most closely related known sample being S. newyorkensis, (Accession Number GU994085) with a fully matched 16SrDNA. S. newyorkensis is a gram-positive endospore-forming bacteria from the Sporosarcina genus that has been identified in human blood and raw cow's milk (Wolfgang et al., 2012). The presence of S. newyorkensis is unknown in the deep-ocean floor and it was unknown whether it could be used in MICP treatment. S. newyorkensis is classified as BSL 1 (being a low-risk 
microbe that poses little threat for infection in healthy adults) by the Japanese Society for Bacteriology and can be used in MICP treatment tests.

\subsection{Evaluation of the MICP tests}

\subsubsection{Results of the liquid phase urease activity tests}

The levels of urease activity of S. newyorkensis, S. pasteurii and S. aquimarina at different temperatures and $101.325 \mathrm{kPa}$ pressure are shown in Fig. 6 . The maximum urease activity was at $4^{\circ} \mathrm{C}$ for S. newyorkensis and $20^{\circ} \mathrm{C}$ for S. pasteurii. S. newyorkensis was kept at low-temperature and high-pressure conditions in the P-core sample; it survived these conditions until the bacteria isolation process began. These results suggest that, under the same nutrient conditions, S. newyorkensis may have a similar strengthening effect at $4^{\circ} \mathrm{C}$, as S. pasteurii has at $20^{\circ} \mathrm{C}$, making it more applicable to cold temperatures. When comparing the highest values, S. aquimarina showed less than half the urease activity of the other two microbes. However, temperature had a minimal influence.

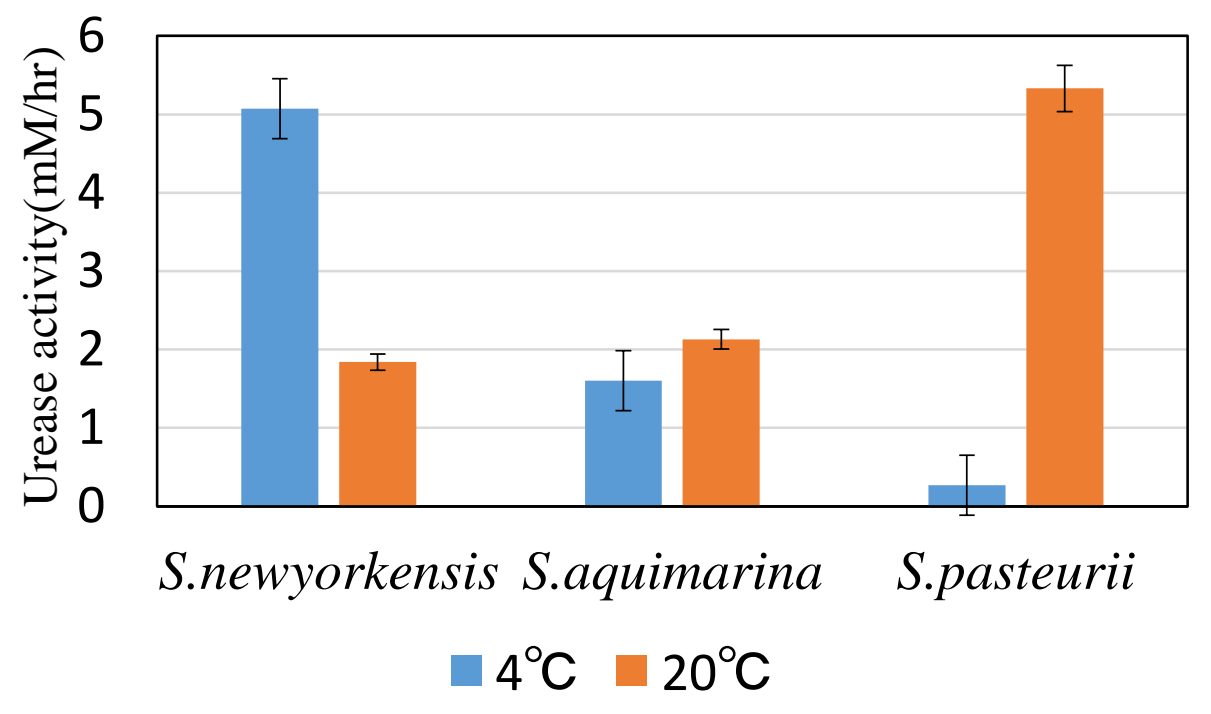

Figure 6. Results of urease activities.

These results suggest that $S$. aquimarina can be applied across varying temperatures with low urease activity; however, it was also found that S. newyorkensis has a high suitability for MICP at the lowtemperature conditions of the deep-sea floor.

\subsubsection{Results of the liquid phase microscopy tests}


Results have shown that the newly isolated bacterium has a high possibility of success for MICP treatment; however, the calcium carbonate precipitation rate and the morphology of these calcium carbonate crystals needs further investigation through microscopy. The crystallisation speed of $S$. newyorkensis would be expected to be the same as that of $S$. aquimarina and one-third of that of $S$. pasteurii at $20^{\circ} \mathrm{C}$. Results are shown in Fig. 7 wherein the mesh size is $500 \mu \mathrm{m}$. The left images of Fig. 7 show the first crystals during the test term, and the right images indicate the final formation of the calcium carbonate crystals after 24-h cultivation. The fastest crystal-forming microbe is $S$. pasteurii, which indicates high-urease activity at $20^{\circ} \mathrm{C}$. The other two microbes, S. aquimarina and S. newyorkensis, worked more slowly and generated their first crystals after two or three hours of cultivation. The final crystal shapes and sizes depended on the microbial species. S. pasteurii created a lot of small crystals with an average crystal size of 10 to $100 \mu \mathrm{m}$. S. aquimarina and S. newyorkensis created larger calcium carbonate crystals that were rounder and larger than those of the S. pasteurii with an average crystal size of 100 and $400 \mu \mathrm{m}$. These tests indicate that the newly isolated microbe, S. newyorkensis, precipitates carbonate precipitation differently compared with the well-known MICP-applicable microbe, S. pasteurii. Clarà Saracho et al 2020b investigated the mineralogy, morphology, and properties of the $\mathrm{CaCO}_{3}$ biominerals and found that different polymorphs may be precipitated by the different microbial species. The influence of these differences in the calcium carbonate crystal structure on the soil behaviour must be investigated. 


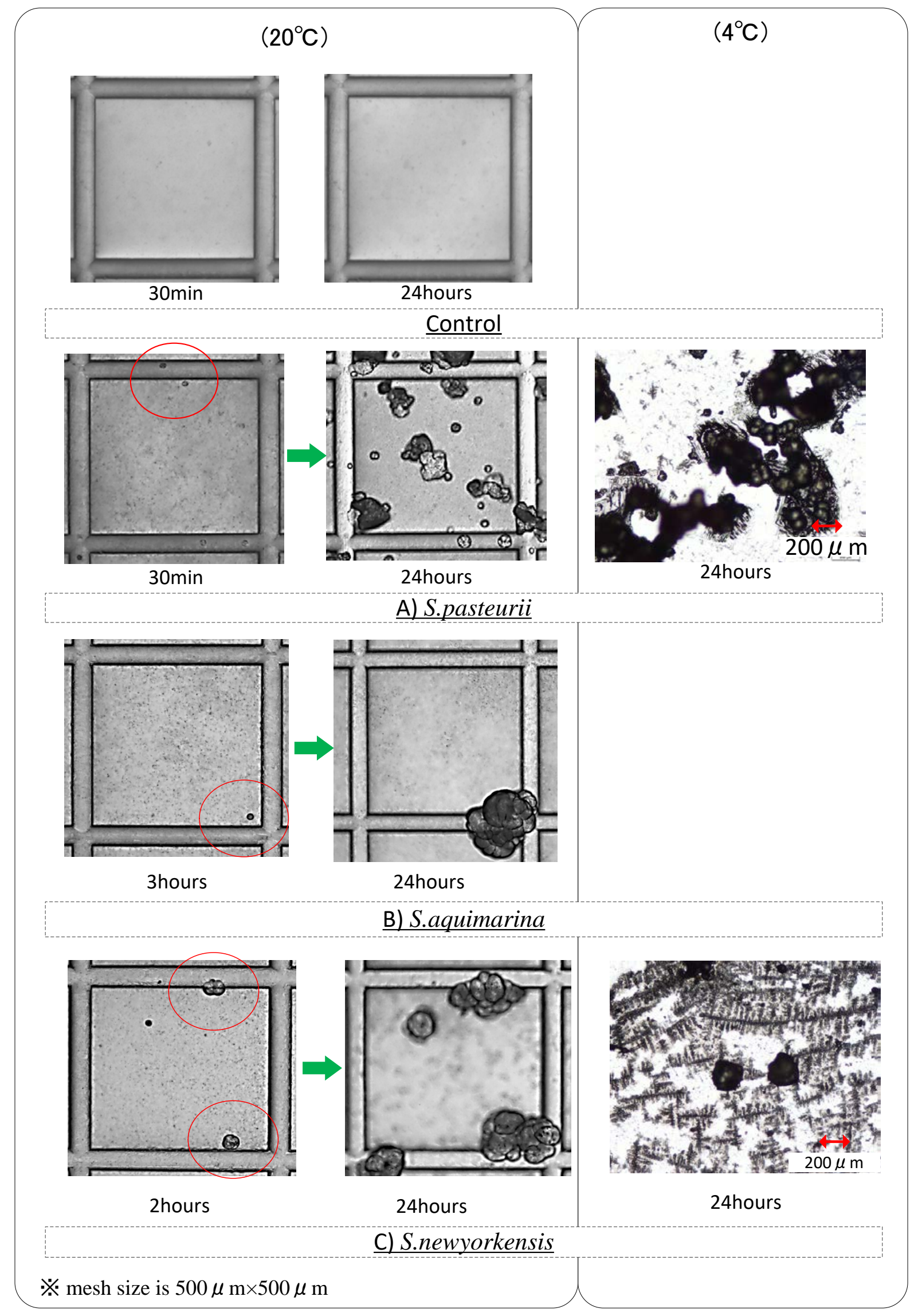

Figure 7. Results of calcium carbonate crystal formation. 


\subsubsection{Results of the solid-phase tests}

CD triaxial tests were performed with effective confining stresses of 50,100 and $150 \mathrm{kPa}$. Results of the $C D$ test at an effective confining stress of $100 \mathrm{kPa}$ are shown in Fig. 8. Results of the CD tests with different amounts of carbonate formation were interpreted based on a cohesion and internal friction angle, as shown in Table 1 and Fig. 9. The peak strength of the CD tests increased with the number of injections. At an effective confining stress of $100 \mathrm{kPa}$, one treatment increased the specimen's peak strength by $10 \%$ in comparison with the untreated case whereas three injections increase the peak strength by $30 \%$.

Table 1. Results of CD tests (cohesion and internal friction angle)

Items Control One injection Three injections

\begin{tabular}{cccc}
\hline \hline Cohesion (c) & 3.6 & 3.9 & 8.0 \\
\hline Internal friction angle $(\varphi)$ & 34.5 & 36.1 & 36.8
\end{tabular}
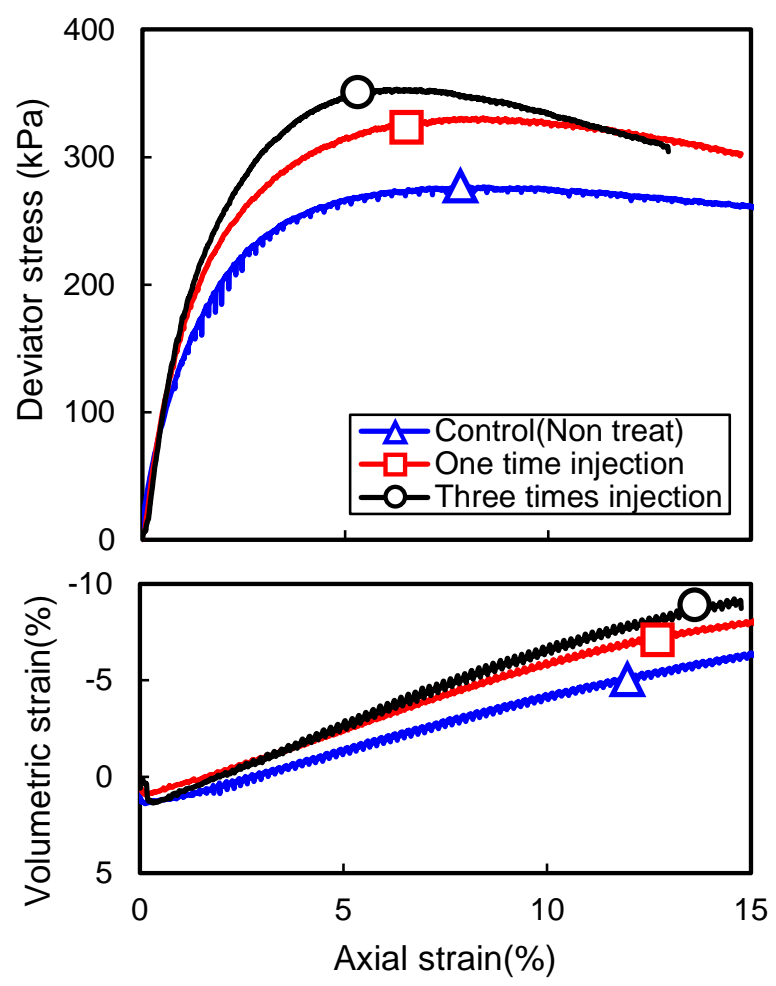

Figure 8. Results of the CD tests (the effective restraint pressure is $100 \mathrm{kPa}$ ). 


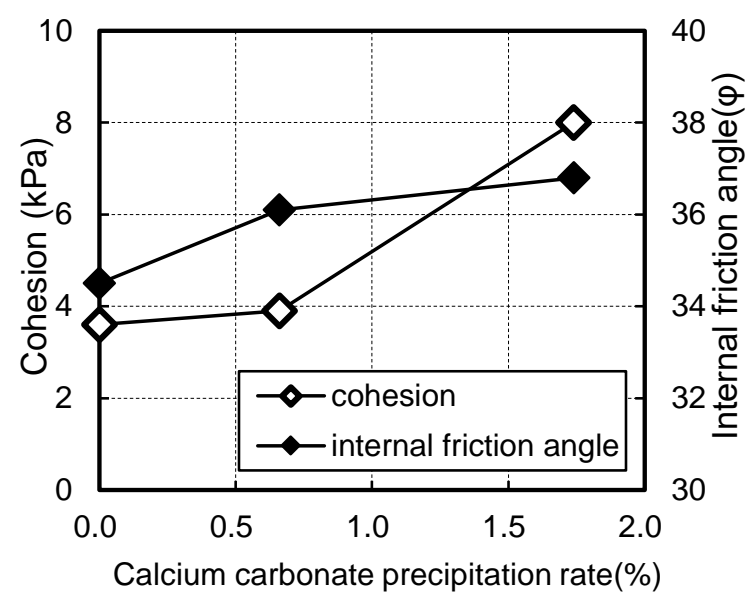

Figure 9. Relationship between calcium carbonate precipitation rate and $C$ and $\varphi$.

After the CD tests, the specimens' calcium carbonate precipitation content was measured with the acid digestion method (using $1 \mathrm{M}-\mathrm{HCl}$ ). The content relative to the soil weight is $0.6 \%$ (one injection) and $1.74 \%$ (three injections). This result suggests that the increase in calcium carbonate crystals has a strong relationship with the increase in soil strength.

The soil strength increases after MICP treatment which can be evaluated by calculating cohesion c and internal friction angle $\varphi$ parameters from linear fits to the triaxial data. From Figure 9 it can be seen that the value of the internal friction angle increases slowly with the number of injections (calcium carbonate precipitation rate), little change being seen after the first injection while the cohesion value continued to increase with multiple injections but was little affected by the first. These results suggest that MICP treatment with S. newyorkensis has two types of soil strength enhancement mechanisms related to the calcium carbonate precipitation content. At low calcium carbonate precipitation condition (less than 1\%), the precipitated crystals bonded with the sand particles and increased the shear strength based on the bonding effect caused by the increment of internal friction angle. In this step, the pore space network will be maintained, and water can through the specimens, maintaining the original soil permeability. This type of treatment can be used to mitigate the risk of sand production while avoiding a reduction in gas-production rate.

An increase in the number of injections will increase the $\mathrm{CaCO}_{3}$ content, filling up the soil pores and increasing the cohesion. This will clog the pore network and decrease the soil's permeability. By applying this stage of the treatment, unexpected water production that harms gas productivity can be inhibited. 
The next step is to evaluate the relationship between the calcium carbonate precipitation rate and soil permeability with laboratory permeability tests.

\section{Conclusions}

In this study, we evaluated the influence of the P-core operation on the analysis of microbial diversity and isolation of target microbes without biological contamination. We also studied the possibility of MICP treatment with newly isolated bacteria from a P-core sample from the Nankai Trough. A pressurisation process needs to be added to the P-core sample process to maintain stable methane hydrate conditions and reduce the contamination risk from the pressurising distilled water. These results conclude the P-core operation can maintain the microbial diversity of the sample without biological contamination and the native high pressure and low temperature.

The proposed microbial isolation steps could maintain microbial diversity while focusing on the enhancement of the target species under the nutrient-rich condition. Thus, the microbial isolation processes were completed in almost one month. It was found that deep-ocean microbes can still survive in the methane hydrate stable area, their population can be increased, and their diversity altered to focus on urease-production bacteria in short-term cultivation. Moreover, the isolation of the urease-producing microbes (S. newyorkensis) had unique characteristics that showed higher urease activities under low-temperature conditions. The newly isolated bacteria, S. newyorkensis, had already been identified in human blood and raw cow's milk (Wolfgang et al., 2012). However, it has never been found below the deep-ocean floor.

S. newyorkensis can enhance calcium carbonate precipitation with cultivation in a calcium chlorideand urea-rich medium at conditions representative of the deep-sea bed. These results indicate higher possibilities of MICP treatments by applying deep-seabed ground improvement works. The ground improvement efficiency, which focusses on the deep-seabed layer with these microbes, represents the strength increment with the number of cementation solution injections. Based on these results, the soil strength can be maintained with a number of injections of $0.3 \mathrm{~mol} / \mathrm{L}$ (urea concentration and calcium chloride solution).

The mechanism of enhanced soil strength has two phases that include bonding (at a $1 \%$ calcium carbonate precipitation rate) and clogging (above $1 \%$ calcium carbonate precipitation rate). These two mechanisms each have potential uses in preventing sand and water production. 
This study demonstrates the strong potential of the newly isolated bacterium S.newyorkensis to promote MICP treatment, which begins with urea hydrolysis and accelerates calcium carbonate precipitation by S. newyorkensis. However, the influence of high-pressure conditions is not clear with this experiment.

In future, additional experiments should be performed focusing on the influence of high-pressure conditions on S.newyorkensis treatment. These will allow the permeability reduction effect to be evaluated allowing sand production in the deep-sea to be reduced. 


\section{Acknowledgements}

The authors are grateful to Dr. Edward Kavazanjian, Director, NSF Engineering Research Center for Bio-mediated and Bio-inspired Geotechnics, and Dr. Taku Oshima of Toyama Prefectural University for their constructive suggestions and reviews on certain aspects of this project.

Funding: This study was conducted as part of the activity of MH21-S R\&D consortium as planned by the Ministry of Economy, Trade and Industry, Japan. We would like to express our sincere thanks for the support. This research was partially supported by a Japan Society for the Promotion of Science Grant in Aid for Scientific Research ([B] JP19H02239) and a Grant in Aid for Challenging Exploratory Research (JP17K18909).

Conflict Of interest: The authors have no conflicts of interest directly relevant to the content of this article. 


\section{References}

Al Qabany, A.A., and Soga, K., 2013. Effect of chemical treatment used in MICP on engineering properties of cemented soils. Géotechnique 63(4), 331-339.

Bang, S.S., Galinat, J.K., and Ramakrishnan V., 2001. Calcite precipitation induced by polyurethaneimmobilized Bacillus pasteurii. Enzyme Microb. Technol. 28(4-5), 404-409.

Clarà Saracho, A., Haigh, S., 2018a. Experimental optimization of microbially induced calcite precipitation (MICP) for contact erosion control in earth dams. In Scour and Erosion IX: Proceedings of the 9th International Conference on Scour and Erosion (ICSE 2018), November 5-8, 2018, Taipei, Taiwan, chapter Book chapt, pp. 43-50. CRC Press,Taipei.

Clarà Saracho, A., and Haigh, S., 2018b. Microbially Induced Calcite Precipitation (MICP) to mitigate contact erosion in earth dams and levees. In 38th USSD Annual Conference and Exhibition. United States Society on Dams.

Clarà Saracho, A., Haigh, S.K., J orat, M.E. (2020a) Flume study on the effects of microbial induced calcium carbonate precipitation (MICP) on the erosional behaviour of sand. Geotechnique, doi: 10.1680/jgeot.19.p.350 (in press)

Clarà Saracho, A., Haigh, S.K., Hata, T., Soga, K., Farsang, S., Redfern, S.A.T. \& Marek, E. (2020b) Characterisation of $\mathrm{CaCO}_{3}$ phases during strain-specific ureolytic precipitation. Scientific Reports 10, 10618. doi:10.1038/s41598-020-66831-y

Dejong, J.T., Soga, K., Kavazanjian, et al. 2013. Biogeochemical processes and geotechnical applications: progress, opportunities and challenges. Géotechnique. 63(4), 287-301.

Dickens, G., Paull, C., Wallace, P., 1997. Direct measurement of in situ methane quantities in a large gas-hydrate reservoir. Nature 385, 426-428.

Fujii, T., Nakamizu, M., Tsuji, Y. et al. 2009. Methane-hydrate occurrence and saturation confirmed from core samples, eastern Nankai Trough, Japan. In Natural Gas Hydrates-Energy Resource Potential and Associated Geologic Hazards (T. Collett, A. Johnson, C. Knapp \& R. Boswell (eds)). American Association of Petroleum Geologists, 89.pp.385-400.

Hata, T., Suetsugu, D., Kawachi, A. et al. 2019. Development of an eco-friendly bio-based granular geomaterial for the environmental restoration of Ichkeul Lake, Tunisia.Euro Mediterr. J. Environ. Integr. 4(1): 21. 
Hata, T., Yokoyama, T., Abe, H., 2013. Investigation of a soil improvement technique for coastal regions on the basis of calcium carbonate precipitation by using the urea hydrolysis rate. Jpn. Geotech. J. 8(4), 505-515. (in Japanese).

Inada, N., Yamamoto, K., 2015. Data report: Hybrid Pressure Coring System tool review and summary of recovery result from gas-hydrate related coring in the Nankai Project, Mar. Petrol. Geol., 66, 323-345, http://dx.doi.org/10.1016/i.marpetgeo.2015.02.023

Japan Geotechnical Society (JGS):Method for consolidated-drained triaxial compression test on soils(JGS0524)

Jiang, N-J., Soga, K., 2017. The applicability of microbially induced calcite precipitation (MICP) for internal erosion control in gravel-sand mixtures. Géotechnique. 67(1), 42-55.

Jiang, N-J., Soga, K., Kuo, M., 2016. Microbially Induced Carbonate Precipitation for SeepageInduced Internal Erosion Control in Sand-Clay Mixtures . J. Geotech. Geoenviron. Eng. 143(3).

Jin, Y., Konno, Y., Yoneda, J., Kida, M, Nagao, J. (2016). In situ Methane Hydrate Morphology Investigation: Natural Gas Hydrate-bearing Sediment Recovered from the Eastern Nankai Trough Area. Energy Fuels 30 (7), 5547-5554. doi: 10.1021/acs.energyfuels.6b00762

Kubo, Y., Mizuguchi, Y., Inagaki, F., Yamamoto, K., 2012. A new hybrid pressure-coring system for the drilling vessel Chikyu, Sci. Dril., 17, 37-43, doi.org/10.5194/sd-17-37-2014

Montoya, B.M., DeJong, J.T., 2015. Stress-strain behavior of sands cemented by microbially induced calcite precipitation. J. Geotech. Geoenviron. Eng. 141(6).

Muyzer, G., de Waal, E. C., Uitterlinden, A. G. 1993. Profiling of complex microbial populations by denaturing gradient gel electrophoresis analysis of polymerase chain reaction-amplified genes coding for 16S rRNA. Appl. Environ. Microbiol. 59(3), 695-700.

Pettigrew, T., 1992. The design and preparation of a wireline pressure core sampler (PCS), ODP Technical Note No. 17, 291.

Priest, J.A., Druce, M., Roberts, J., Schultheiss, P., Nakatsuka, Y., Suzuki, K., 2015. PCATS Triaxial: A new geotechnical apparatus for characterizing pressure cores from the Nankai Trough, Japan, Mar. Petrol. Geol. 66, 460-470.

Sanger, F., Nicklen, S., Coulson, A.R., 1977. DNA sequencing with chain-terminating inhibitors. Proceedings of the National Academy of Sciences of the United States of America. 74(12), $5463-5467$. 
Santamarina, J.C., Dai, S., Terzariol, M., Jang, J., Waite, W.F., Winters, W.J., Nagao, J., Yoneda, J., Konno, Y., Fujii, T., Suzuki, K., 2015. Hydro-Bio-Geomechanical Properties of Hydrate-Bearing Sediments from Nankai Trough. Mar. Petrol. Geol. 66, 434-450. doi: /10.1016/j.marpetgeo.2015.02.033

Suzuki, K., Schultheiss, P., Nakatsuka, Y., et al. 2015. Physical properties and sedimentological features of hydrate-bearing samples recovered from the first gas hydrate production test site on Daini-Atsumi Knoll around eastern Nankai Trough. Mar. Petrol. Geol. 66, 346-357.

Takahashi, H., Tsuji, Y., 2001. Multi-well exploration program in 2004 for natural hydrate in the Nankai Trough offshore Japan. In: Offshore Technology Conference, Houston, TX, 2005. https:doi.org/10.4043/17162-MS

Terzis, D., Laloui, L., 2019. Cell-free soil bio-cementation with strength, dilatancy and fabric characterization. Acta Geotech. 14, 639-656.

Van Paassen, L.A., 2009. Biogrout (ground improvement by microbially induced carbonate precipitation) [Ph.D. Thesis]. Delft University of Technology).

Whiffin, V. S., Van Paassen, L.A., Harkes, M.P., 2007. Microbial carbonate precipitation as a soil improvement technique. Geomicrobiol. J. 24(5), 417-423.

Whiffin, V.S., 2004. Microbial $\mathrm{CaCO}_{3}$ precipitation for the production of biocement [Ph.D. Thesis]. http://researchrepository.murdoch.edu.au/id/eprint/399. Murdoc University, Western Australia.

Wolfgang, W.J., Coorevits, A., Cole, J.A., et al. 2012. Sporosarcina newyorkensis sp. nov. from clinical specimens and raw cow's milk. Int. J. Syst. Evol. Microbiol. 62(2), 322-329.

Yamamoto, K., 2015. Overview and introduction: pressure core-sampling and analyses in the 2012_2013 MH21 offshore test of gas production from methane hydrates in the eastern Nankai Trough. Mar. Petrol. Geol. 66, 296-309.

Yoneda J, Masui A, Konno Y et al. (2015) Mechanical behavior of hydrate-bearing pressure-core sediments visualized under triaxial compression. Marine and Petroleum Geology 66: 451-459.

Yoneda, J., Masui, A., Konno, Y., Jin, Y., Kida, M., Katagiri, J., Nagao, J., Tenma, N.,(2017). Pressure-core-based reservoir characterization for geomechanics: Insights from gas hydrate drilling during 2012-2013 at the eastern Nankai Trough. Mar. Petrol. Geol. 86, 1-16. doi: /10.1016/j.marpetgeo.2017.05.024 
Yoon, J.H., Lee, K.C., Weiss, N., et al. 2001. Sporosarcina aquimarina sp. nov., a bacterium isolated from seawater in Korea, and transfer of Bacillus globisporus (Larkin and stokes 1967), Bacillus psychrophilus (Nakamura 1984) and Bacillus pasteurii (Chester 1898) to the genus Sporosarcina as Sporosarcina globispora comb. nov., Sporosarcina psychrophila comb. nov and Sporosarcina pasteurii comb. nov., and emended description of the genus. Int. J. Syst. Evol. Microbiol. 51(3), 1079-1086. 